音声言語医学 $47 ： 294-297,2006$

\title{
聴覚障害教育におけるリテラシーと手話活用
}

\author{
小田 侯朗
}

\begin{abstract}
要 約：わが国の聴覚障害教育における手話の活用とリテラシーの関係について，近年の聾 学校を対象としたコミュニケーション手段の比較研究等を基に概括した. 聴覚障害児のリテラ シーについては過去から現在に続く聴覚障害教育の主要なテーマであり，また手話や口話とい ったコミュニケーション手段がリテラシーの伸展に与える効果の比較についても関心がもたれ てきた。本論では国立特殊教育総合研究所が行ったコミュニケーション手段とリテラシーの関 連についての研究を紹介した。結果的には聴覚障害児のリテラシーに影響を与える要因はさま ざまであり，多様な手段を複合したアプローチが求められる。本論では最近わが国でも話題に なってきた聴覚障害児のバイリンガル教育に打けるリテラシーへのアプローチについても解説 を行った.
\end{abstract}

索引用語：手話, リテラシー，聴覚障害

\section{Japanese Literacy and the Use of Sign Language in Deaf Education in Japan}

\section{Yoshiaki Oda}

\begin{abstract}
This paper discusses the use of sign language for developing Japanese literacy in deaf children, based on research into deaf education in Japan. In the 1980's, the National Institute of Special Education (NISE) conducted comparative research on schools for the hearing impaired that use various communication modes and elementary schools for hearing children. The results show that various factors work in tandem with the communication modes (oral, cued speech, and simultaneous) for developing Japanese literacy in deaf children. It should be recognized that literacy comprises various activities: reading, writing, daily communication, background knowledge, and so on. The paper also explains some of the main instructional techniques using a bilingual approach for developing Japanese literacy in deaf children.
\end{abstract}

Key words: sign language, literacy, deaf

\section{はじめに}

古くから聴覚障害教育においてはコミュニケーショ ンの力の育成が大きな柱とされてきた。特に読み書き

の力（リテラシー）については社会参加の重要な要因
と考えられ，さまざまな工夫がなされてきた。しかし ながら，時代によりリテラシーのとらえ方，あるいは そこに期待されるものも変化してきている，本論では 手話を活用したリテラシーへのアプローチを考えるう えで理解しておきたいこれまでの研究や現状について

独立行政法人国立特殊教育総合研究所：２399-0841 神奈川県横須賀市野比 5 丁目 1 番 1 号

National Institute of Special Education: 5-1-1 Nobi, Yokosuka, Kanagawa-prefecture, 239-0841

2006 年 5 月 15 日受理 
概説したい.

聴覚障害教育における手話活用の歴史は長く，その 始まりとともに手話，あるいは現在の手話に連なるよ うな手指による視覚的伝達を目的とした手段が用いら れてきた.わが国においても 1878 年の京都盲啞院設立 当時から聴覚障害児への指導法として手話（校長古河 太四郎は「手勢」という語を使用）が用いられてきた。 その後, 口話法の世界的な普及に合わせ, わが国でも 手話から口話へという指導法抢よびコミュニケーショ ン方法の転換が見られた。戦後はテクノロジーの進歩 などに支えられ聴覚を活用する指導方法がクローズア ップされ, 聴覚口話法と称される方法が聴覚障害教育 の主流となってきた. 聴覚口話法に対する期待が膨ら むなかで，手話の教育的使用はどちらかというと時代 遅れのかつ聴覚障害者集団という狭い社会に閉じこも ったものであるとのイメージが形成されていったと考 える. しかしながら, 障害者の社会参加の進展, 特に 手話を生活やさまざまな活動の核とする聴覚障害者集 団の活発な社会参加や，諸外国の手話活用実践などの 紹介等から, 改めて手話の教育的活用に対する関心が わが国でも高まっているところである.

手話の教育的利用について考える前に理解しておか なければならないことは，手話がすでに過去からあり 続けているものであり, これまで聴覚障害者のさまざ まな活動を支えてきたものであり，言語として社会的 に機能しているものであるということである．したが って新しく開発されたものの効果を確かめるようなつ もりで手話の効用を議論するのではなく, すでに生活 の重要な一部となっている言語としてとらえていく態 度が求められるものである. 本論では「手話とリテラ シー」の関係について概観していくつもりであるが, 基本的に，手話は日本語のリテラシーを向上させるた めに開発された手段ではない。日本語のリテラシーを 向上させなければ，手話には存在の意味はないという ものでもない。そこに存在し続けている手話という言 語の多様な機能のなかに, 日本語のリテラシーの進展 に寄与する機能があり，それを安定して支える指導法 や学習環境についての議論が現在深まりつつあるとと らえるべきであろう。本論では日本に扔ける手話活用 教育と日本語のリテラシーの関係について検討された いくつかの研究を紹介しながら, このテーマについて の現状や課題を概括する.

\section{日本における比較研究}

日本の聴覚障害教育における手話の活用を取り上げ

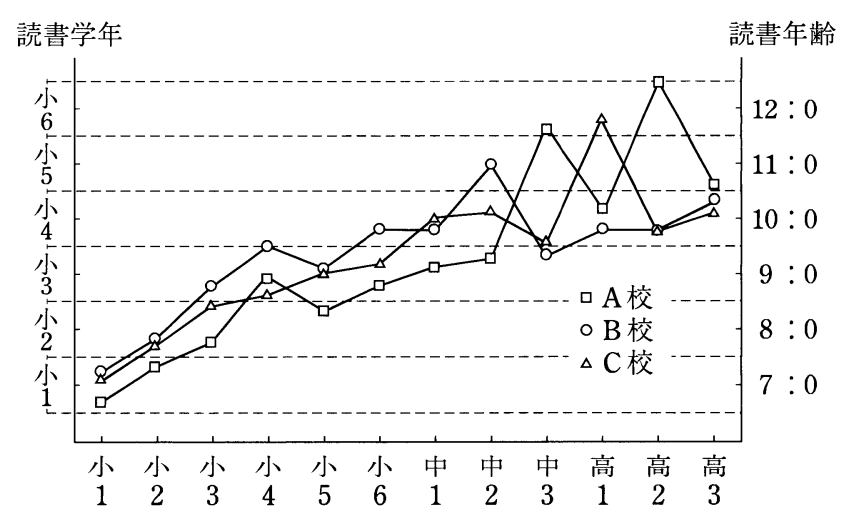

図 1 読書年齢の学年的推移に関するコミュニケーション・ モードの比較 (我妻敏博, $1983^{11}$ より転載)

たものに, 国立特殊教育総合研究所の研究がある ${ }^{1)}$. こ こでは図 1 に示される 3 つの壟学校を対象として，そ れぞれの学校に在籍する児童生徒の読書力が比較検討 された. 3 つの学校の 1 つ目は聴覚口話法を指導法と し，手話やキュードスピーチなどの視覚的手段を用い ない学校（A校）であった。2 つ目は聴覚口話法を基 本にしながらキュードスピーチを積極的に活用する学 校（B校）であった。そして 3 つ目は聴覚・口話・手 話・指文字を日本語の体系を支えるものとして総合的 に用いる指導法をとる学校（C校）であった。この 3 校の比較は, 結果として大きな差のないものとなった.

さらに国立特殊教育総合研究所では, 引き続く研究 において 2 つ学校を追加して児童生徒の日本語に関 する読みの力の比較研究を行った ${ }^{2)}$. 追加したのは通 常の小学校 1 校と聴覚口話法を指導法とする壟学校 1 校であった。それぞれの学校の児童を対象に物語り文 の読解力を調査したこの結果からは, 指導法の違い以 外の課題が明らかになった(図 2 ). 結果を全体的に見 ると通常の小学校の生徒の成績が最も良く，それに近 い形で新しく追加した聴覚口話法を方針とする聾学校 の成績が示された。その後にやや低い成績でキュード スピーチや手話・指文字を用いる学校の結果が示され， 最も低い成績としてもう 1 校の聴覚口話法を指導の方 針とする学校が位置づけられることになった。すなわ ち, 壟学校 4 校の最も成績の良い学校と, 最も成績の 低い学校に聴覚口話法が位置したのである。ここで対 象とされた龍学校の同一学年に在籍する児童生徒の数 は，決して多くはない。ちなみに図 1 においてはキュ ードスピーチを用いる学校のある学年は 2 名の在籍児 童数となっている.この 2 名の成績がキュードスピー チによる指導の当該学年の教育効果として一般化され るにはやはり問題もあろう。ただ，近年のわが国の壟 


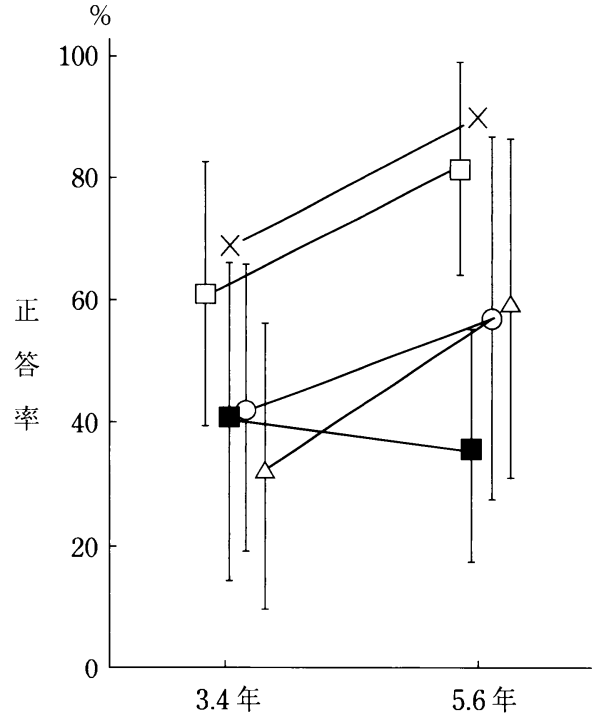

図 2 物語文の読解力に関するコミュニケーションモードの比 較 (我妻敏博, $1986^{2}$ ) 一部修正して転載). $\times$ : 小学校 (新規追加)， $\square:$ 聴覚口話法校 (新規追加)， $\mathbf{\square}$ : 聴覚口 話法校, $\bigcirc$ : キュードスピーチ活用校, $\triangle$ : 手話・指文 字活用校, 縦軸は 1 標準偏差を示す。

学校を対象とした調査では，在籍児童の減少や在籍児 のいない学年の存在, そして，在籍児の障害の多様化 はまれではなくむしろ一般的なことといえる，指導法 の比較にはこのような課題が常に関係している。

ちなみに，同時期に行われたアメリカにおける聴覚 障害児の読書力テストに関する大規模な調査結果を見 ると (図 3), 国立特殊教育研究所の調査結果と類似し た傾向を確認することができ，被検児数の少なさがこ の調査を意味のないものにしているということではな いことも確認できるであろう ${ }^{31}$.

聴覚口話法を標榜する襲学校の間に成績の差がある ことについては，対象児に左右される要因だけではな く, 教員の実際の指導法の課題や広い意味での言語・ コミュニケーション環境の差異が挙げられるだろう。 また，使用するコミュニケーション手段とは別に，リ テラシーの向上を学校目標として明確化しているかど うかなど, 教育の力点の違いも差として現れる要因で ある。

手話に関して述べるなら，上記の 2 つの調査におけ る手話の教育的活用が, 現在議論されている手話の活 用と多少異なる面をもつことに触れておくべきであろ う。聴覚障害教育におけるバイリンガル教育に代表さ れるように，近年の手話活用では，その国の音声言語 とは異なる体系をもつ独自の言語としての手話の活用 に関心が集まっている。しかし前述の学校比較のなか で用いられている手話は，日本語の手指表現という性

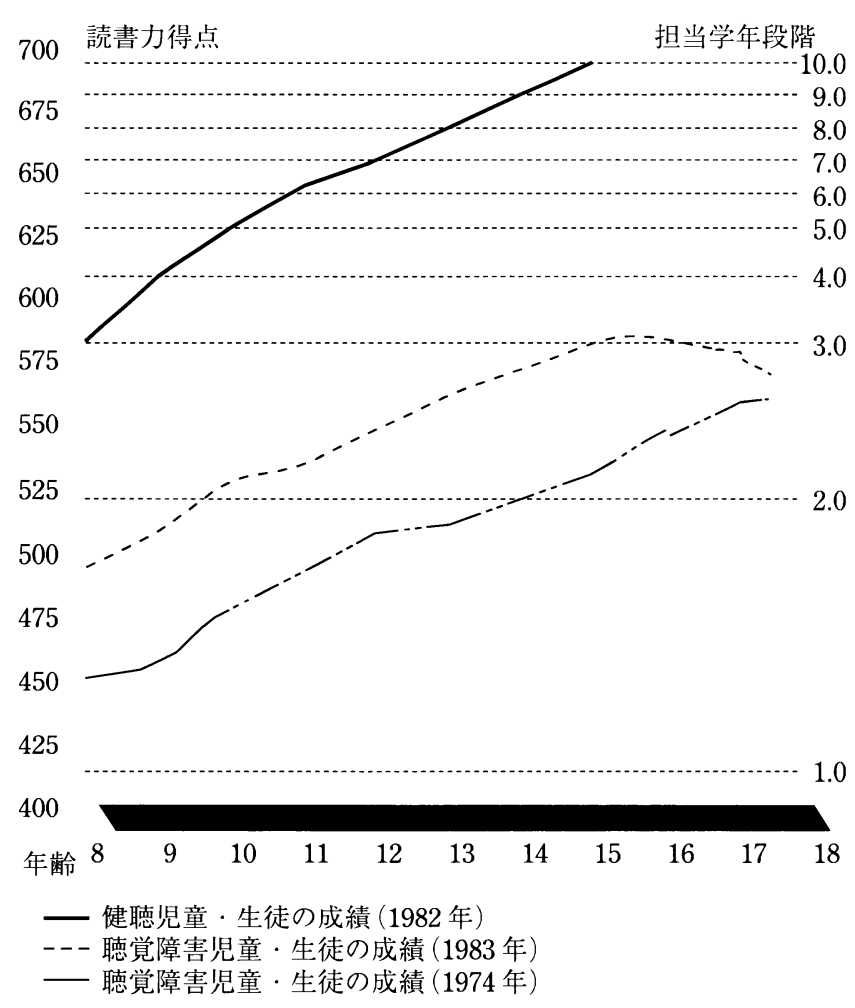

図 3 年齢ごとに見た聴覚障害児童・生徒の読書力の平均得点 (中野善達, 他訳, $1992^{3)}$ より転載)

資料: T.E. Allen, "Patterns of Academic Achievement Among Hearing-Impaired Students: 1974 and 1983” In A.N. Schildroth and M.A. Karchmer (eds), Deaf Children in America (San Diego, Calif.: College Hill Press, 1986), p. 164.

格が強く，基本的には日本語の体系に沿って用いられ る手話・指文字である。その点では，これらの学校の 指導法は共通してモノリンガル教育であったといえ る.

手話を音声言語とは異なった言語と考え，その国の 主要な音声言語（特にその書記体）と手話の異なった 2 つの言語を効果的に用いて教育を進めようとするの が聴覚障害児のためのバイリンガル教育である．移民 などに対する一般的なバイリンガル教育では，第一言 語がすでに家庭やコミュニティでのコミュニケーショ ンを通して確立されており，課題は第一言語を用いな がら第二言語の力をどのように効果的に伸ばすかにな る.聴覚障害児のためのバイリンガル教育の場合には, 第一言語の機能的な確立がまず課題となるため, バイ リンガル教育も手話環境の整備に焦点を当てた第一言 語確立段階と, 手話と音声言語（の書記体を中心に） の 2 つの言語の効果的使用を目指寸第二段階に分けら れるのが一般的であろう。ただし，近年は早い時期か ら音声言語（とその書記体）の導入を考元，早期から 
のバイリンガル状況を設定する試みも見られるように なっている。

\section{手話とリテラシー}

さて本論のテーマである「手話とリテラシー」に戻 るが, 聴覚障害児のバイリンガル教育に扔いても, 児 童生徒は手話を通してのみ音声言語のリテラシー（読 み書き能力）を身に付けるわけではない。たとえば， 手話と日本語（の書記体）の関係で述べるなら，学習 しょうとする内容についてあらかじめ手話で理解する ことが, 後の書きことばの理解を支えるという 2 言語 の関係がある。この場合に用いられる手話は, 日本語 にとらわれる必要はなく学習者が快適に理解できる手 話を用いることが重要になる。たとえていうならば, 日本語使用者が英文を読むときに，あらかじめその内 容を日本語で解説されたうえで英文にアプローチする ような状況である。次に日本語の単語や文法の形態を 手指表現に対応づけながら確認する手話の使用法があ る.この用法にはその目的により幅がある。上述した ような独自の言語体系である手話（日本手話という呼 称を用いる場合もある）のなかに日本語の単語や文を 借用する場合には，指文字や漢字に対応した手指表現 の組み合わせを用いたりすることがある。この場合， 手話表現と日本語の音韻の対応が十分学習されてない 語に対して, サンドイッチのように手話表現・指文字 表現・手話表現，あるいは指文字表現・手話表現・指 文字表現と表現を繰り返す場合も見られる。 また，教 師が日本語の形式で手指表現による説明や問いかけを 行い, それに対して児童生徒が，同様に日本語の形式 で意見や回答を手指表現する場合も見られる。このよ うな形式の手指表現を日本語対応手話と呼称する場合 もある。ささらには本語の読み書きを通して日本語を 理解するという，より一般的な学習の過程も，バイリ ンガル教育において当然見られるものである。日本語 のリテラシーがある程度確立した後には，この書きこ とばを通して日本語を理解するプロセスがより重要に なってくる．これと平行してバイリンガル教育では手 話で議論をし，手話で考える経験を大切にする。また
手話の表現力を高める活動を積極的にとらえる。これ は日本語のリテラシーを高めるというよりは, 言語活 動そのものを高めることにより, 言語一般がもつ構造 や機能について理解を深め, 結果的に日本語という言 語のもつ構造や機能に対する理解を深めることにつな がるものである。

このような活動が円滑に進められるためには聴覚障 害児がアクセスしやすく, かつ質の高い日本語と手話 の言語環境が求められる。そのためには日本語と手話 の堪能な児童への関わり手が重要になる，学校教育の 場面では, 日本語と手話を機能的に使用できる教職員 の存在が欠かせない.また授業や自主学習を支える日 本語教材や手話教材の充実が必要になる。今後は教職 員の手話研修や教材の充実, そして指導法の検討およ び積み重ねが聴覚障害教育の課題となってゆくであろ う。このように考えてくるとコミュニケーション手段 とリテラシーの伸展とを直接関連づけることの問題点 がより明確になってくる。

聴覚障害者がその生活のなかで用いてきた手話やそ の他の手段を最大限の敬意をもって教育のなかで活用 し，学習者にとって快適で効果的な指導法を開発する ことがリテラシーをはじめとする聴覚障害教育の課題 を解決していく道であると考える。

\section{文献}

1）我妻敏博：聴覚障害児の「読み」の能力. 国立特殊教育総 合研究所特別研究報告書「手指法等の評価と適応に関する 研究」:61-66, 1983.

2）我妻敏博：聴覚障害児における物語文の読解力と感想文の 分析. 国立特殊教育総合研究所特別研究報告書「壟児・聾 精神薄弱児等の言語習得と多様なコミュニケーションの応 用に関する研究」：51-60, 1986 .

3）中野善達, 根本匡文編訳 : 新しい聴覚障害教育をめざして, 湘南出版社, 1992.

別刷請求先：干 239-0841 神奈川県横須賀市野比 5 丁目 1 番 1 号 独立行政法人国立特殊教育総合研究所 小田侯朗 